\title{
State Formation in Riau Islands Province
}

\author{
By Mulya Amri and Faizal Rianto
}

\section{EXECUTIVE SUMMARY}

- The formation of the Riau Islands Province (RIP) in 2002 is argued to be part of a broader trend of pemekaran (blossoming) that saw the creation of seven new provinces and more than 100 new districts throughout Indonesia after the fall of the New Order.

- This article argues that the main motivation for these subnational movements was a combination of rational interests and cultural sentiments.

- In the case of RIP, rational interests involved struggles over unfair distribution of power and resources, including the way development under the control of (mainland) Riau Province had been detrimental to the peripheral and archipelagic people of Riau Islands.

- Cultural sentiments also played an important role, as the people of the Riau Islands considered themselves as "archipelagic Malays" and heirs of the great Malay-maritime empires of the past, as opposed to "mainland Malays" who were mostly farmers.

- Since becoming its own province, RIP has been performing well and has surpassed Riau, the "parent" province, in multiple aspects including human development, poverty alleviation, and government administration.

- Ultimately, the formation of RIP is argued to be a natural process in a large, diverse, and decentralizing country like Indonesia, where cultural identities are being reasserted and local autonomies renegotiated.

- Despite the usual hiccups such as capacity gaps and corruption, the formation of the Province has been positive in achieving a balance between keeping the country intact while allowing local stakeholders a substantial level of autonomy. 
